\title{
Is there a Long-Term Relationship among European Sovereign Bond Yields?
}

\author{
Ian Schaeffer and Miguel D. Ramirez \\ Department of Economics, Trinity College, 300 Summit Street \\ Hartford, CT 06106. USA \\ E-mail: Miguel.Ramirez@trincoll.edu
}

Received: November 4, 2016 Accepted: November 30, 2016

doi:10.5296/ber.v7i1.10863 URL: https://doi.org/10.5296/ber.v7i1.10863

\begin{abstract}
The integration of financial markets has been a recurring theme in academic and financial research. The majority of the literature has focused on equity markets. Literature on the integration of international bond markets is not as common, specifically regarding that of European bonds since the beginning of the common currency area in 1999.

This paper estimates a fixed effects pooled model and then proceeds to undertake panel unit root and cointegration tests to determine the degree of co-movement of European sovereign bond yields. The reported estimates suggest that yields move together over time, thus the benefits of diversification in European government bond portfolios may be limited. The results also have important implications for monetary policy. Given that economic shocks (e.g. inflationary shocks) are transmitted quickly from country to country, then it will complicate the task of monetary policy when it comes to pursuing an independent policy with respect to domestic monetary conditions in the presence of asymmetric economic shocks.
\end{abstract}

Keywords: European Monetary Union, Fully modified ordinary least squares (FMOLS), Pairwise Granger Causality tests, Panel unit roots, Panel cointegration, Sovereign bond yields

JEL: C23; N23; O52

\section{Introduction}

Over the past few decades, the global liberalization of financial markets has resulted in increased interdependence among international markets. A prime example of interdependence among international markets exists on the European continent. The European Monetary Union has played a huge role in the integration of Europe's capital and money markets. As a result of this integration, European government bond markets accounted for over $55 \%$ of all 
withstanding bonds in the Euro area in the years following the implementation of the monetary union (Pagano and Von Thadden 2004). Recent years have seen the global financial crisis spawn a sovereign debt crisis within Europe. Since 2009, European government bond markets have been shaken, resulting in multiple rescue packages from the International Monetary Fund and a debate on everything from the best short-term response to the long-term stability and sustainability of the euro area (Arghyrou and Kontonikas 2011; and Andreas, 2014).

This paper explores the long-term relationship among European sovereign bond yields in order to evaluate the benefits of diversification in a government bond portfolio and the complications for European monetary policy. The empirical analysis focuses on twelve countries, eleven of which currently use the euro as their national currency and a twelfth which has its own currency and monetary policy. Panel data from 12 countries are analyzed using a fixed effects model. Finally, this paper uses the Pedroni cointegration test to investigate the presence of long-run relationships among bond yields and estimates a Fully Modified Ordinary Least Squares (FMOLS) model. Since the previous work related to this topic focuses on both different sets of countries and time periods, this study makes a positive contribution to the extant literature by providing both updated evidence and more robust econometric results.

The paper is organized as follows: The next section reviews the extant literature and past research regarding testing for long-term relationship among sovereign bond yields. The third section introduces the conceptual model and discusses the sample data. Section four discusses the empirical model and presents the estimates generated by the various models as well as various econometric tests. Finally, section five presents the conclusions and policy implications of the findings.

\section{Literature Review}

Literature discussing European sovereign bond market integration is rare in the post-2008 period. The vast majority of previous literature focuses on the time period just before or just after the establishment of the monetary union and the European Central Bank. While there has been a limited amount of theoretical work done on the subject of European financial integration since 2008, there has been even less empirical analysis on the topic. Swanson (2008), for example, shows that during the period between the Maastricht Treaty and the inception of the common currency, euro area bond yields converged greatly with the anticipation of monetary union and the credibility of the yet-to-be-formed European Central Bank (ECB). From 1999 until mid-2008, 10-year bond yields across the euro area converged even more. However, once the 2008 financial crisis hit, this story of yield convergence takes a turn for the worse.

Clare, Maras, and Thomas (1995) present a study on the integration of the bond markets of the United Kingdom, the United States, Germany, and Japan from 1978 to 1990. Using the familiar Engle and Granger methodology, the authors find low correlations between the mentioned bond markets in the long run compared to stock market returns. These results point to diversification benefits derived from investing in the bond markets during this time 
period. In contrast, Taylor and Tonks (1989) use similar cointegration techniques and Granger causality tests to examine stock market integration in the United Kingdom, West Germany, the Netherlands, Japan, and the United States, from 1973 to 1986. Their evidence suggests that the stock market of the United Kingdom is cointegrated with German, Dutch, and Japanese stock markets. These results yield the implication that the reduction in long-run risk from diversification will be slight.

By contrast, Mills and Mills (1991) examine the 5-year government bonds of the US, the UK, West Germany, and Japan from 1986 to 1989. They conduct cointegration analysis using the more powerful Johansen and Juselius approach. They find that bond yields are determined by their own domestic fundamentals in the long run, i.e. bond yields are not cointegrated. Mills and Mills also conduct impulse response tests, which measure the response of each variable to a unit innovation in the other variables. They find that shocks in one bond market are quickly transmitted to other bond markets. This suggests that yield movements in the bonds of one country contribute to and affect yield movements in other countries.

Clare and Lekkos (2000) examine the globalization of financial markets in the context of the efficacy of an independent monetary policy. Monetary policy typically affects the short end of the term structure of government bonds. However, if we assume that rates on the long end of the structure are determined by short term interest rate expectations, then monetary policy would affect the entire term structure. If the long-term relationship (cointegration) among government bonds is significant, then the ability of monetary policy makers to influence the term structure may be put in jeopardy. Clare and Lekkos find that during periods of extreme financial turmoil (such as the 1992 sterling exchange rate crisis, the 1997 Asian crisis, and the 1998 Russian debt crisis) yields respond primarily to international factors. This suggests that international economic crises will need to be controlled for in any long-term relationship analysis of bond yields. The authors' examination of US, German, and UK government bond markets also suggest that risk premia (both temporary and permanent) and contagion effects played an important role in influencing yields from 1990 to 1999. These results suggest that some fundamental factors may need to be controlled for in the long-term relationship analysis of this thesis.

De Santis (2012) builds a model to analyze bond yields over the period 1 September 2008 to 4 August 2011. His model controls for current and future forecasts of government budget deficits, government public debt (credit ratings), consensus forecast of inflation and real GDP growth, liquidity risk factors, and regional and international aggregate risk factors (spread between U.S. triple-B corporate bond and U.S. treasury of the identical maturity). The author finds that credit risk is statistically significant and contributes to higher yield spreads in Greece, Ireland, Portugal, and Spain. Additionally, liquidity risk played a minor role and international risk factors were not a variable that could explain the crisis. De Santis also finds significant spillover effects among countries, particularly when the effect originates from Greece.

Pagano and Von Thadden (2004) compare yield differentials (sovereign bond yield differentials compared to the German 10-year benchmark bond) on European sovereign debt 
from both before and after the inception of the common currency. They find that the persistence of yield differentials under the EMU for sovereign debt signifies that euro area bonds are not perfect substitutes. However, they note that this persistence in yield differentials is not a reflection of continued market segmentation but rather differing fundamental risks, such as default risk or the possibility of the collapse of the EMU exchange risk. Laopodis (2008) suggests that since these differences in bond market liquidity or default risk among countries cause yield differentials, benefits from portfolio diversification are possible within the monetary union. Laopodis uses the Johansen and Juselius approach to test for long-term relationships, or cointegration, among euro area bond yields. He finds no long-term relationship among euro area bond markets in the pre-euro time period (1 January 1995 to 1 December 2000) but does find evidence of a "weak" long-term relationship during the post-euro period (1 January 2001 to 27 July 2006). Additionally, Laopodis uses the Granger causality test to determine if there is any unidirectional or bidirectional causality among European bonds. He uses an error-correction term in the post-euro and without an error-correction term in the pre-euro period in these tests. He finds a higher degree of bivariate linkages among all euro area bond markets during the post-euro period compared to the pre-euro period. Additionally, he finds that the UK sovereign bond markets do not have Granger-causality influences on the euro area bond markets in both specified time periods.

Laopodis notes that yield differentials among euro area government bonds are likely to decrease as the euro area becomes more and more integrated over time. However, Laopodis did not anticipate the severity of the 2008 economic downturn in his claim (as many others also failed to do). Nevertheless, it should be noted that yield differentials will decrease given increased European economic integration. For policymakers in Europe, higher correlations among government bonds will lead to a greater transmission of economic shocks according to Laopodis. This increased risk could lead to adverse consequences for the stability of the monetary union.

\section{Conceptual Model}

This study uses panel data to analyze the long-term relationship among government bonds in the euro area and the United Kingdom. Thus, cointegration analysis is used to test for a long-term relationship. Additionally, this paper controls for numerous factors that could affect the relationship among bond yields. For example, differences in liquidity may cause an underlying difference in bond yields among countries, and certain exogenous or idiosyncratic shocks may cause bond yields to exhibit greater volatility or move erratically for short periods of time, possibly skewing the empirical results of cointegration analysis. For this reason, it may be beneficial to use bond yield data of a lower frequency. Using high frequency data (e.g. daily bond yield data) may lead to the inclusion of short-term shocks. Using data of medium or longer-term frequency may abate this problem by excluding unpredictable yield movements of an extreme short-term nature.

Panel data also tend to exhibit either deterministic or stochastic trends over time. Panel data can therefore be non-stationary. Non-stationarity in a data set could lead to the misspecification of results or spurious regressions; the R-squared values and F- and 
t-statistics may become inflated, resulting in inaccurate and unreliable conclusions. Given that this study analyzes the long-term relationship among macroeconomic variables, non-stationarity (or unit roots) may be present in the data. Therefore, it will be necessary to test for panel unit roots and non-stationarity before thoroughly developing the appropriate panel data model. This paper undertakes various econometric tests for the presence of unit roots, including the Levin, Lin, and Chu test for panel unit roots.

There are two traditional types of panel data models: (1) the fixed effects model, and (2), the random effects model. Each type has its own advantages and disadvantages. The fixed effects model treats the constant as group or section specific. Each intercept, while possibly different from all other intercepts, is included to capture time-invariant factors; within-group estimators can solve this issue by using the time variation from each cross-sectional unit. The downside to the use of the fixed effects model to capture time-invariant factors is the loss of degrees of freedom associated with the use of dummy variables, as well as the potential presence of multi-collinearity.

The random effects model includes a random variable for each cross section. Of course, this involves making assumptions about the distribution of the random component of the model. Compared to the fixed effects model, the random effects model has two main advantages: (1) the random effects model includes a smaller number of parameters to estimate, and (2), the random effects model allows for the addition of variables that have equal explanatory power for all observations in a group. Additionally, the random effects model assumes that the sample is from a larger universe of data. The Hausman Test, described below, can aid in determining which model best suits a set of panel data.

Given that this study will encompass a variety of countries with time-invariant cultures, histories, and economies, it would be logical to assume that the fixed effects model would be the more appropriate model to select. Thus, the estimated fixed effects model is:

$$
y_{i t}=\beta x_{i t}+\alpha_{i t}+D_{i}+\varepsilon_{i t}
$$

where there are $k$ regressors in $x_{i t}$ excluding the constant term and $D_{i}$ represents dummy variables. The fixed effects model assumes that differences across units can be captured in the differences in the group-specific constant term $\alpha_{i}$ (Greene 2002). The fixed constant here is time-invariant; the term "fixed" does not necessarily imply that the constant is nonstochastic. Each constant term is treated as an unknown parameter.

The data will consist of 12 cross-sectional regressors for $\mathrm{i}=1, \ldots, 12$ and monthly observations from 1995 through 2013 resulting in 228 time periods for each variable, $\mathrm{t}=1, \ldots$, 228 for a total of 2,736 observations. ${ }^{1}$ European 10-year sovereign bond yields from 12 countries will be the dependent variables, which will be a function of numerous independent

\footnotetext{
1 The included countries (cross sections) are Austria, Belgium, Finland, France, Germany, Italy, Ireland, The Netherlands, Portugal, Spain, The United Kingdom, and Greece.
} 
variables. Following the lead of Laopodis (2008) and Arghyrou and Kontonikas (2011), the formulation of the stacked regression model is as follows:

$$
(Y)_{i t}=f\left[(C R)_{i t},(B A S)_{i t},(I N F)_{i t-1},(I R)_{i t},(V O L)_{i t} ; D_{i}\right]+\varepsilon_{i t}
$$

where the regressand, Y, is the sovereign bond yield for the 10-year maturity segment. Bond yield data are obtained from FRED Economic Data, St. Louis Federal Reserve Bank. The model includes the following regressors: the credit rating (CR) as a proxy for differences in default risk among countries; the bid-ask spread of each country compared to the 10-year German bund (BAS) to account for varying levels of liquidity and resulting risk; the rate of inflation (INF); the interest rate (IR); a measure of market volatility (VOL); and dummy variables $\left(D_{i}\right)$ to account for various exogenous variables. $\varepsilon_{i t}$ is a normally distributed error term.

The credit rating (CR) serves as a direct indicator of default risk for each country, which will impact bond yields. As the default risk increases or overall financial stability of a country decreases, the credit rating will go down. The expected sign of the CR variable is negative, indicating a negative relationship between credit rating and bond yields; as the credit rating of an economy decreases, the sovereign bond yields of that economy should increase because investors will demand a higher premium for the added risk of investment. The credits ratings in this model are provided by Fitch, which provides the most number of years of data on European credit ratings out of the big three credit agencies (the other two being Standard \& Poor's and Moody's). The CR variable is constructed through the creation of an index series ranging from zero to one hundred with one hundred being a AAA rating. Each one-tier decrease in credit rating corresponds to a decrease of five in the constructed index. For example, a credit rating of AAA, AA+, and AA correspond to a 100, 95, and 90 in the index.

A variable (BAS) accounting for the bid-ask spread of sovereign bonds is included to reflect the varying levels of liquidity from country to country. The larger the spread between the bid price and asking price, the lower the liquidity. In turn, lower liquidity represents a greater risk for buyers of sovereign bonds since the investment may not be able to be "liquidated" quickly enough to minimize losses. Therefore, the expected sign of the bid-ask spread variable is positive; as the bid-ask spread increases, yields will also increase. The bid-ask spread data is obtained from Bloomberg.

The rate of inflation (INF) is lagged in order to gauge the effect of shifting expectations on the required return (yield) of a bond. Inflation is expected to have a positive sign in the model, reflecting the fact that as inflation increases bond yields rise to compensate investors for the loss of purchasing power. Inflation data are obtained from Organization for Economic Cooperation and Development (OECD). The European Central Bank's interest rate on the deposit facility (the rate at which European banks make overnight deposits) will be used as the interest rate variable (IR) in the model. This data are provided by the ECB Statistical Data Warehouse. The interest rate is expected to have a positive effect, given that as interest rates rise yields must also rise in order to stimulate demand for bonds via increased returns. It 
should be noted that data on this interest rate is not available for the entire time period since the ECB was founded around the turn of the millennium. The final independent variable, VOL, uses the Deutsche Borse VDAX Volatility Index. This volatility index measures overall volatility in the German equity markets; this index was chosen for its ample available data (most volatility indices do not cover the entire sample period of this model). The volatility variable is expected to have a negative effect. Heightened or increasing volatility will spur a flight to safety among the markets, leading to investors opting for government bonds as a safer investment over other riskier securities. This will boost demand for bonds causing bond prices to rise and yields to fall, ceteris paribus. Data on this volatility index are provided by Bloomberg.

This model attempts to account for numerous economic shocks, volatile time periods, and exogenous variables through the use of dummy variables $D_{i}$. $D_{1}, D_{2}$, and $D_{3}$ are dummy variables accounting for, respectively, the Peso crisis which occurred as a result of the December 1994 devaluation of the Peso via-à-vis the dollar, the Asian debt crisis triggered in July of 1997, and the 1998 Russian debt crisis. All of these crises potentially affected the expected convergence of European sovereign bonds arising from the establishment of the euro area in 2000. $D_{4}$ accounts for the July/August 2012 time period immediately following the remarks of ECB president Mario Draghi asserting that he will do "whatever it takes" to save the euro. These remarks may have caused unpredictable yield movements during a specific time period.

The model controls for differences in default risk among countries and differences in liquidity levels among countries. Following the lead of De Santis (2012), this study controls for liquidity risks by using data on bid-ask spreads of the 10-year maturity segment. Controlling for these two exogenous variables is crucial to the estimation of the model as the level of yield convergence may be skewed by fundamental differences in default and liquidity risks.

\section{Empirical Results}

The Durbin-Wu-Hausman test determines whether the Fixed Effects Model (FEM) or the Random Effects Model (REM) is more appropriate for a given set of data. The null hypothesis of the test is that the REM is appropriate, while the alternative hypothesis is that the FEM is more appropriate. The results of the Hausman test are shown in Table 1. The Hausman chi squared statistic is significant at the 5\% significance level, indicating that we can reject the null hypothesis and proceed in estimating a Fixed Effects Model. 
Table 1. Hausman Test

\begin{tabular}{|c|c|c|c|c|}
\hline \multicolumn{4}{|c|}{ Correlated Random Effects - Hausman Test } & \\
\hline \multicolumn{3}{|c|}{ Pool: COUNTRIES } & & \\
\hline \multicolumn{4}{|c|}{ Test cross-section random effects } & \\
\hline \multicolumn{2}{|c|}{ Test Summary } & Chi-Sq. Statistic & Chi-Sq. d.f. & Prob. \\
\hline \multicolumn{2}{|c|}{ Cross-section random } & 99.609843 & 5 & 0.0000 \\
\hline \multicolumn{5}{|c|}{ Cross-section random effects test comparisons: } \\
\hline Variable & Fixed & Random & Var(Diff.) & Prob. \\
\hline BAS & 3.049636 & 3.243263 & 0.000438 & 0.0000 \\
\hline CR & -0.119262 & -0.103293 & 0.000003 & 0.0000 \\
\hline $\operatorname{INF}(-1)$ & -0.029882 & -0.055563 & 0.000021 & 0.0000 \\
\hline IR & 0.553393 & 0.527350 & 0.000008 & 0.0000 \\
\hline VOL & 0.016471 & 0.015339 & 0.000000 & 0.0000 \\
\hline
\end{tabular}

\subsection{Fixed Effects Model}

The initial FEM reported in Table 2 below shows that all independent variables are significant and all coefficients have the anticipated sign with the exception of inflation (INF) and volatility (VOL). This is a curious result given that, theoretically, higher inflation should be associated with higher bond yields as investors need to be compensated. The negative inflation coefficient indicates that as inflation rises, bond yields decrease and bond prices increase.

Other variations of this FEM were estimated and are available upon request. For example, when the interest rate (IR) variable is removed from the equation, the coefficient for inflation gains the expected positive sign. It is possible that this effect is due to the fact that interest rate data goes only back to December of 1998. When IR is included in the FEM, a significant part of the data set is removed. This restriction could affect the coefficient on inflation. The conflicting results regarding the sign of the coefficient of INF could also arise from the fact that the inflation data used is ex-post, not ex-ante. In other words, the inflation data used in this model measures actual inflation levels rather than expected levels.

In addition, dummy variables $D_{1}, D_{2}$, and $D_{4}$ corresponding to the Peso crisis, the Asian crisis, and Mario Draghi's July 2012 comments respectively are all significant. The first two significant dummy variables have a positive coefficient, indicating that during those periods of economic crisis, yields increased due to depressed demand for government bonds. In all likelihood, this was due to the spillover effects of the unexpected Peso and Asian crises. The dummy variable corresponding to the Russian debt crisis is not significant. The latter crisis occurred during the aftermath of the Asian crisis and did not have as large of a surprise element. The final dummy variable has a negative and significant effect. This indicates that Mario Draghi's pledge to save the Eurozone at any cost pushed yields lower. This is particularly evident in Italian and Spanish bonds (see Figure 1) as their yields sharply decreased following Draghi's comments. Once the markets gained confidence in the stability 
of the Eurozone and the continued inclusion certain economies (namely Spain and Italy) in the common currency area, investors became more willing to buy government debt. As demand for bonds increased, yields decreased. Thus, a negative coefficient for $D_{4}$ is logical.

Table 2. FEM Regression Output with Cross-Section Weights

\begin{tabular}{|c|c|c|c|c|}
\hline \multicolumn{3}{|l|}{ Dependent Variable: Y } & & \\
\hline \multicolumn{4}{|c|}{ Method: Pooled EGLS (Cross-section weights) } & \\
\hline \multicolumn{4}{|c|}{ Sample (adjusted): 1998M12 2013M12 } & \\
\hline \multicolumn{4}{|c|}{ Included observations: 181 after adjustments } & \\
\hline \multicolumn{3}{|c|}{ Cross-sections included: 12} & & \\
\hline \multicolumn{4}{|c|}{ Total pool (unbalanced) observations: 2133} & \\
\hline Variable & Coefficient & Std. Error & t-Statistic & Prob. \\
\hline $\mathrm{C}$ & 10.40093 & 0.292065 & 35.61167 & 0.0000 \\
\hline BAS & 4.747095 & 0.211159 & 22.48112 & 0.0000 \\
\hline $\mathrm{CR}$ & -0.076626 & 0.003176 & -24.12598 & 0.0000 \\
\hline $\operatorname{INF}(-1)$ & -0.126841 & 0.015149 & -8.372989 & 0.0000 \\
\hline IR & 0.625310 & 0.014257 & 43.86091 & 0.0000 \\
\hline VOL & 0.013601 & 0.001632 & 8.332158 & 0.0000 \\
\hline \multicolumn{5}{|l|}{ Fixed Effects (Cross) } \\
\hline AT--C & 0.134249 & & & \\
\hline BE--C & -0.441558 & & & \\
\hline DE--C & -0.226456 & & & \\
\hline EL--C & -0.192169 & & & \\
\hline ES--C & 0.250212 & & & \\
\hline FI--C & 0.012393 & & & \\
\hline FR--C & 0.040905 & & & \\
\hline IR--C & 0.367807 & & & \\
\hline IT--C & -0.377354 & & & \\
\hline NL--C & 0.051575 & & & \\
\hline PT--C & -0.008523 & & & \\
\hline \multirow[t]{2}{*}{ UK--C } & 0.396010 & & & \\
\hline & \multicolumn{2}{|c|}{ Weighted Statistics } & & \\
\hline R-squared & 0.682148 & \multicolumn{2}{|c|}{ Mean dependent var } & 6.126975 \\
\hline Adjusted R-squared & 0.679745 & \multicolumn{2}{|c|}{ S.D. dependent var } & 2.260116 \\
\hline S.E. of regression & 1.077324 & \multicolumn{2}{|c|}{ Sum squared resid } & 2455.889 \\
\hline F-statistic & 283.8246 & \multicolumn{2}{|c|}{ Durbin-Watson stat } & 0.224811 \\
\hline Prob(F-statistic) & 0.000000 & & & \\
\hline
\end{tabular}

\subsection{Panel Unit Root Tests}

Before testing for cointegration, it is necessary to determine if all variables are stationary via panel unit root tests. If a series is shown to contain a unit root (i.e. the series is non-stationary) 
the series can be rendered stationary through differencing. A series that is stationary after taking the first difference is integrated of order one or I(1). Ideally, all series should be integrated of the same order. However, it is possible to run cointegration analysis even if all variables are not integrated of the same order (Pedroni, 2000).

Several researchers have developed unit root tests designed for panel data. Notably, the Levin, Lin, and Chu test (2002), the Im, Pesaran, and Shin test (2003), and the Hadri test (1999).. These panel unit root tests are more powerful than those carried out on any single series because the information within a time series is strengthened by that contained in the cross section data (Ramirez 2007). This introduces more heterogeneity into the data. In other words, the above researchers have found that type II error (the failure to reject a null hypothesis of non-stationarity) is less likely to occur when using panel unit root tests compared to unit root tests on a single series which are notorious for having low power.

The Levin-Lin-Chu test was used for all pooled variables. Three confirmatory tests were also used for the pooled variables: the Im, Pesaran and Shin (IPS) test, the Augmented Dickey-Fuller-Fisher (ADF-Fisher), and the Phillips-Perron Fisher (PP-Fisher) tests. The Augmented Dickey-Fuller (ADF) test, Kwiatkowski-Phillips- Schmidt-Shin (KPSS) test, and/or the Zivot-Andrews unit root test with one structural break were used for all other variables.

The Levin-Lin-Chu test employs a null hypothesis of a unit root with the following (ADF) specification:

$$
\Delta y_{i t}=\alpha y_{i t-1}+\sum \beta_{i t} \Delta y_{i t-j}+X_{i t}+v_{i t}
$$

where $y_{i t}$ corresponds to the pooled variable, $X_{i t}$ refers to the exogenous variables such as

the cross section fixed effects and $v_{i t}$ represents the independent disturbances or error terms.

The Im, Pesaran and Shin test and ADF Fisher chi-square estimates separate ADF regressions for each cross section. This allows for individual unit roots processes.

Maddala and Wu (1999) demonstrate that the IPS test is more powerful than the LLC test. For both tests the null hypotheses are identical (the presence of a unit root), while the alternative hypotheses are different. The alternative hypothesis of the LLC test is based on homogeneity of the autoregressive parameter. The alternative hypothesis of the IPS test is based on heterogeneity of that same parameter. In other words, the IPS test does not pool the data while the LLC test is based on regressions with pooled data. In addition, Maddala and $\mathrm{Wu}$ note that "when there is no cross-sectional correlation in the errors, the IPS test is slightly more powerful that the Fisher test... Both tests are more powerful than the (LLC) test" (Maddala and Wu 1999: 644).

The summaries of the unit root tests for the pooled variables BAS, CR, and INF are displayed in Appendix A. For BAS, the chi statistic is significant at the 5\% level so we therefore reject the null hypothesis and conclude that BAS does not have a unit root. We fail to reject the null 
hypothesis for CR in level form; however we are able to reject the null hypothesis when CR is differenced and conclude that CR is stationary. For both BAS and CR, all the relevant tests and statistics yield the same conclusion. The unit root tests for INF are contradictory. We fail to reject the null hypothesis in the Levin-Lin-Chu test but do reject the null in the ADF, PP, and Im, Pesaran and Shin tests. Therefore, we can conclude that INF is stationary in level form because the (IPS) test, in particular, controls for both individual fixed effects and individual linear trends.

The results of the unit root tests for the unpooled variables IR and VOL are available upon request. VOL is shown to be integrated of order zero $\mathrm{I}(0)$ according to both the ADF and Zivot-Andrews test. IR has contradictory results in that the ADF test indicates that IR is I(1) while the more powerful KPSS test which defaults to a stationary null (no unit root) indicates that IR is stationary in level form.

In conclusion, all variables are stationary in level form except for the credit rating variables. This result was expected as the credit rating for each country does not change frequently and the series may be prone to exhibiting a trend since a credit rating may follow a long-term increase or decrease to reflect a country's improving or deteriorating economic and/or public finance situation.

\subsection{Panel Cointegration Results}

The Pedroni (2000) cointegration test allows for a considerable amount of heterogeneity in panel data model (see Asteriou and Hall 2011). The null hypothesis of no cointegration differs from that of other cointegration tests (e.g. the McCoskey and Kao test). Pedroni's cointegration tests allow for multiple regressors, varying cointegration vectors across the panel sections, and for heterogeneity in the error terms across cross sections. However, it should be noted that a significant drawback of the Pedroni test is the assumption of a unique cointegrating vector.

The Pedroni test constructs four panel statistics and three group panel statistics to test the null hypothesis. The autoregressive term is assumed to be equivalent across all cross sections in the panel statistics; on the other hand, the parameter can vary over each cross section. In other words, if the null hypothesis is rejected in the panel statistics, the variables are cointegrated for all cross sections (in this case the countries). If the null hypothesis is rejected in the case of the group panel statistics, at least one of the countries is cointegrated. It should be noted that the panel statistics are more restrictive in nature than the group statistics. A rejection of the null hypothesis using the panel statistics indicates that all countries have cointegration among the included variables. On the other hand, a rejection of the null hypothesis using the group statistics indicates that a minimum of one country exhibits cointegration among the included variables.

The results of the Pedroni tests are shown in Table 3 below. Unfortunately, the credit rating variable CR has been omitted due to its inclusion leading to an error in running the test, viz., a singular or non-invertible matrix. It is likely that this error is caused by the very low variance in the credit rating series. It should be noted that the credit ratings for Austria, 


\section{Macrothink}

Business and Economic Research

ISSN 2162-4860

2017, Vol. 7, No. 1

Germany, and the Netherlands are constant (AAA) throughout the entire sample. The weighted statistics for the panel-PP and panel-ADF are both significant at the 5\% level and the group-PP and group-ADF statistics are both significant at the 5\% level. Therefore, we can reject the null hypothesis of no cointegration and conclude that there is cointegration in the model.

Table 3. Pedroni Cointegration Test

\begin{tabular}{|c|c|c|c|c|}
\hline \multicolumn{3}{|c|}{ Pedroni Residual Cointegration Test } & & \\
\hline \multicolumn{2}{|l|}{ Series: Y INF BAS } & & & \\
\hline \multicolumn{2}{|c|}{ Sample: 1995M01 2013M12 } & & & \\
\hline \multicolumn{3}{|c|}{ Included observations: 228} & & \\
\hline \multicolumn{3}{|c|}{ Cross-sections included: 12} & & \\
\hline \multicolumn{3}{|c|}{ Null Hypothesis: No cointegration } & & \\
\hline \multicolumn{5}{|c|}{ Newey-West automatic bandwidth selection and Bartlett kernel } \\
\hline \multicolumn{5}{|c|}{ Alternative hypothesis: common AR coefs. (within-dimension) } \\
\hline & & & Weighted & \\
\hline & $\underline{\text { Statistic }}$ & Prob. & $\underline{\text { Statistic }}$ & Prob. \\
\hline Panel v-Statistic & 1.518615 & 0.0644 & -0.236975 & 0.5937 \\
\hline Panel rho-Statistic & -5.316766 & 0.0000 & -3.559168 & 0.0002 \\
\hline Panel PP-Statistic & -4.138675 & 0.0000 & -3.139838 & 0.0008 \\
\hline Panel ADF-Statistic & -5.011506 & 0.0000 & -2.323483 & 0.0101 \\
\hline \multicolumn{5}{|c|}{ Alternative hypothesis: individual AR coefs. (between-dimension) } \\
\hline & $\underline{\text { Statistic }}$ & Prob. & & \\
\hline Group rho-Statistic & -3.793057 & 0.0001 & & \\
\hline Group PP-Statistic & -2.663814 & 0.0039 & & \\
\hline Group ADF-Statistic & -2.143709 & 0.0160 & & \\
\hline
\end{tabular}

\subsection{Fully Modified Ordinary Least Squares (FMOLS)}

Having established that the panel series are cointegrated, viz., they have a long-term relationship that keeps the series in proportion to one another over time, we turn to generating long-run estimates for Equation (2). Following the lead of Pedroni (2000) and Ramirez (2007), it is methodologically appropriate to utilize the group-mean panel fully modified OLS

(FMOLS) technique to Equation (2) above. The FMOLS estimate of the $\beta$ population parameter for country $i$ is mathematically represented as:

$$
\hat{\beta}_{i}^{*}=\left(X_{i}^{I} X_{i}\right)^{-1}\left(X_{i}^{I} y_{i}^{*}-T \delta\right)
$$

where $y_{i}^{*}$ is the transformed 10-year sovereign bond yield; $T$ is the number of time periods; and $\delta$ is the adjustment parameter for serial correlation. The bias induced by endogeneity is 
eliminated by applying a semi-parametric correction proposed by Phillips and Hansen (1990) into the model. Thus, as Pedroni contends, the FMOLS estimators are "extremely accurate even in panels with very heterogeneous serial correlation dynamics, fixed effects and endogenous regressors." Using Monte Carlo simulations, the author also shows that the FMOLS method generates consistent estimates even in relatively small samples. ${ }^{2}$

The abbreviated FMOLS results are shown in Table 4 below. The bolded t-statistics for the independent variables BAS and CR indicate significance at the 5\% significance level. The full results of the model are reported in Appendix B.

Table 4. FMOLS Results

\begin{tabular}{|c|c|c|}
\hline Variable & Coefficient & t-Statistic \\
\hline BAS & $\mathbf{3 . 0 4 3 5 8}$ & $\mathbf{5 . 6 4 1 2 8 6}$ \\
\hline CR & $\mathbf{- 0 . 1 6 9 4 8 2}$ & $-\mathbf{- 7 . 5 5 1 8 8 3}$ \\
\hline INF & $\mathbf{0 . 1 5 8 6 5 5}$ & $\mathbf{1 . 0 2 4 0 3 2}$ \\
\hline D2 & $\mathbf{3 . 5 3 0 5 3 3}$ & $\mathbf{1 . 2 5 3 5 0 2}$ \\
\hline D3 & $\mathbf{2 . 1 7 2 1 0 1}$ & $\mathbf{0 . 8 9 0 6 1 8}$ \\
\hline D4 & $\mathbf{2 . 6 2 4 7 9 4}$ & $\mathbf{1 . 0 7 2 6 3 1}$ \\
\hline
\end{tabular}

\subsection{Granger Causality Tests}

Finally, this study undertook univariate (non-panel) Pairwise Granger Causality tests to determine the strength and direction of the linkages between bond yields across the countries in the sample. That is, it tried to determine if yield movements in one country precede corresponding yield movements in another country. In general, if German bond yields "Granger cause" French bond yields, then changes in German yields should precede changes in French yields. Therefore, German yields "Granger cause" French yields if the inclusion of lagged values of German yields in a regression of French yields on other variables improves the predictive power of that regression. This study found multiple cases of unidirectional Granger causality. The abbreviated results are listed on the following page. The full results are available upon request.

The results of the Granger causality tests indicate that there are considerable linkages among bond yield movement across countries. As shown in Table 5 below, Greece and Germany were both found to "Granger cause" many countries. Interestingly, Greece was found to "Granger cause" a higher number of countries than Germany despite the large difference in economic size and power. Additionally, Ireland was found to "Granger cause" its fellow GIIPS (Greece, Ireland, Italy, Portugal, and Spain) nations when testing for causality with a

\footnotetext{
${ }^{2}$ In a long panel, like the one utilized in this paper, it is assumed that the errors are normally distributed, and the use of the

FMOLS estimator is warranted. Pedroni (2000) has shown, via small sample Monte Carlo simulations, that the bias (and sampling variance) of the group mean FMOLS estimator (based on the "between" dimension of the panel) is very small, even in extreme cases when both the $\mathrm{N}$ and $\mathrm{T}$ dimensions are as small as $\mathrm{N}=10$ and $\mathrm{T}=10$ (and they become insignificant as the time dimension increases).
} 
one-month lag. However, the reported estimates with a two-month lag show that Ireland "Granger causes" every other country in the sample. These results suggest that yield movements in Irish government bonds will result in yield movements across Europe within a time period of 2 months.

Table 5. Pairwise Granger Causality Results

\begin{tabular}{|ll|}
\hline 1 Lag & \\
\hline Germany Granger Causes & $\begin{array}{l}\text { Austria, Belgium, Greece, Finland, France, } \\
\text { and The Netherlands }\end{array}$ \\
\hline Greece Granger Causes & $\begin{array}{l}\text { Austria, Belgium, Germany, Finland, } \\
\text { France, Ireland, The Netherlands, Portugal, } \\
\text { and The United Kingdom }\end{array}$ \\
\hline
\end{tabular}

\begin{tabular}{|ll|}
\hline 1 Lag \\
\hline Ireland Granger Causes & Greece, Italy, Portugal, Spain \\
\hline
\end{tabular}

\section{Conclusion}

This study has both analyzed and estimated the long-term relationship among European

\begin{tabular}{|ll|}
\hline 2 Lags & \\
\hline Ireland Granger Causes & Austria, Belgium, Finland, France, Germany, \\
& Italy, The Netherlands, Portugal, Spain, The \\
& United Kingdom \\
\hline
\end{tabular}

sovereign bond markets during the 1995-2013 time period, using empirical models similar to those proposed by Arghyrou and Kontonikas (2011), Laopodis (2008), and De Santis (2012). The conceptual model hypothesizes that bond yields were positively or negatively affected by different internal and external variables. Namely, the bid-ask spread, inflation, and the interest rate were expected to be positively related to bond yields, while the credit rating and equity market volatility were expected to have a negative relationship with government bond yields. By and large, these hypothesized relationships were confirmed by the reported estimates for the fixed effects model. However, the coefficients for the inflation and volatility variables were not of the expected sign in the initial regressions. The unexpected results regarding the sign of the inflation variable may be due to its ex-post nature, viz., the data measures actual inflation levels rather than an agents' future expectations about inflation. Similarly, the coefficient for volatility matched expectations once a lag was introduced into the series. This may indicate that the flight from equity markets to bond markets due to heightened equity market volatility is not immediate; investors and the markets take time to react to spikes in volatility.

The fixed effects model also showed dummy variables $D_{1}, D_{2}$, and $D_{4}$ to be statistically significant at the 5\% level. The only dummy variable that was not significant was that 
accounting for the Russian debt crisis of 1997; it is possible that this variable was not significant because it did not have the same surprise element as the other economic crises; in other words the Russian debt crisis may have been expected as a spillover from the Asian crisis of 1998. The two dummy variables that had a positive coefficient were those accounting for the 1994-95 Mexican Peso crisis and the 1997-98 Asian crisis. The positive coefficient suggests that the markets were concerned about spillover effects from Mexico and Asia into the European government bond markets; therefore, during the time of these two crises, demand for government bonds fell and yields increased. Out of the three statistically significant dummy variables, only the one corresponding to Mario Draghi's "whatever it takes" speech in July of 2012 had a negative coefficient. This indicates that yields were pushed lower and prices higher after his comments, suggesting that the markets began to demand more government debt as confidence in the stability of the euro area was restored.

Finally, this study undertook a panel unit root and cointegration analysis. It found that all variables were stationary in level form with the exception of the credit rating variable, CR. This was somewhat expected since the credit rating of any country in the sample did not change frequently. Therefore, the variance of the credit ratings was relatively low. However, since all other variables were found to be integrated of order zero, this thesis proceeded to keep all variables in level form.

The Pedroni cointegration test was used to determine if there was a unique long-run relationship in the model. The weighted statistics for the panel-PP and panel-ADF were found to be statistically significant at the $5 \%$ level and the group-PP and group-ADF statistics were found to be significant at the $5 \%$ level. Hence, we rejected the null hypothesis of no cointegration and concluded that there is a long-term relationship in the model.

This paper also found considerable evidence of unidirectional Granger causality. That is, Germany, Greece, and Ireland "Granger caused" multiple countries in the sample. The results of the Granger causality tests demonstrate that movements in yields in one country are quickly transferred to yield movements in other countries. In other words, an economic shock that affects sovereign bond yields in one country is prone to rapidly spread to and affect yields in other countries.

There are important economic and policy implications that can be drawn from this study. The presence of cointegration suggests that the benefits of diversifying a portfolio of European government bonds may not be as pronounced. Since it was found that bond yields move together over time, investing in one government bond over another will not bring higher (or lower) returns in the long run. In other words, since bond yields and prices move together over the long-run, buying only one type of European sovereign bond would theoretically give the same long-run returns as buying a basket of bonds.

Additionally, the cointegration of bond markets and the widespread Granger causality among bonds yields complicates the task of monetary policymakers at the ECB. If bond yields move together over time (as indicated by the results of the Pedrioni test) and economic shocks are spread rapidly from country to country (as the results of the Granger causality tests have indicated), then it may become more difficult to develop a well-targeted monetary policy. If 
bonds across Europe move together, identifying the source of an economic shock will become more challenging because government bond yield are all moving in the same direction. Essentially, integrated European bond markets complicate the task of developing a tailored monetary policy for individual countries in the Eurozone, particularly in the presence of asymmetric economic shocks.

\section{References}

Abad, P., Chhulia, H., \& Gomez-Puig, M. (2009). EMU and European Government Bond Market Integration. European Central Bank Working Paper Series, No. 1079.

Adepoju, A. A., \& Olamide, E. I. (2013). Estimating Seemingly Unrelated Regressions with First Order Autoregressive Disturbances. Studies in Mathematical Sciences, 6(2), 40-57.

Arghyrou, M., \& Kontonikas, A. (2011). The EMU sovereign-debt crisis: Fundamentals, expectations and contagion. European Economy - Economic Papers, 436.

Asteriou, D., \& Hall, S. G. (2011). Applied Econometrics (2 ${ }^{\text {nd }}$ ed.). Palgrave Macmillan.

Baele, L., Ferrando, A., Hordahl, P., Krylova, E., \& Monnet, C. (2004). Measuring Financial Integration in the Euro Area. European Central Bank Occasional Paper Series, No. 14.

Bloomberg. https://www.bloomberg.com/

Clare, A., \& Lekkos, I. (2000). An analysis of the relationship between international bond markets. Bank of England Working Paper Series. No. 123.

Clare, A., Maras, M., \& Thomas, S. (1995) The Integration and Efficiency of International Bond Markets. Journal of Business Finance \& Accounting, 22(2), 313-322.

https://doi.org/10.1111/j.1468-5957.1995.tb00687.x

De Santis, R. (2012). The Euro Area Sovereign Debt Crisis: Safe Haven, Credit Rating Agencies and the Spread of the Fecer from Greece, Ireland and Portugal. European Central Bank Working Paper Series. No. 1419.

European Central Bank (ECB). Statistical Data Warehouse. http://sdw.ecb.europa.eu/

Ehrmann, M., Fratzscher, M., Gurkaynak, R. S., \& Swanson, E. T. (2011). Covergence and Anchoring of Yield Curves in the Euro Area. The Review of Economics and Statistics, 93(1), 350-364. https://doi.org/10.1162/REST_a_00055

Engle, R. F., \& Granger, W. J. (1987). Co-Integration and Error Correction: Representation, Estimation, and Testing. Econometrica, 55(2), 251-276. https://doi.org/10.2307/1913236

FRED Economic Data, Federal Reserve Bank of St. Louis. https://fred.stlouisfed.org/

Gandolfo, G. (2002). International Finance and Open-Economy Macroeconomics. Springer.

Greene, W. (2003). Econometric Anaylsis. (5 ${ }^{\text {th }}$ ed.).Prentice Hall.

Hatzigeorgiou, A. (2014). The Greek Economic Crisis - Is the Euro to Blame? World Economics, 15(3), 143-162. 


\section{Macrothink}

Business and Economic Research ISSN 2162-4860 2017, Vol. 7, No. 1

Im, K. S., Pesaran, M. H., \& Shin, Y. (2003). Testing for unit roots in heterogeneous panels. Journal of Econometrics, 115(1), 53-74. https://doi.org/10.1016/S0304-4076(03)00092-7

Laopodis, N. T. (2008). Government Bond Market Integration within European Union, International Research Journal of Finance and Economics, 19, 56-76.

Levin, A., Lin, C.-F., \& James Chu, C.-S. (2002). Unit root tests in panel data: asymptotic and finite-sample properties. Journal of Econometrics, 108(1), 1-24.

https://doi.org/10.1016/S0304-4076(01)00098-7

Maddala, G. S., \& Wu, S. (1999). A Comparative Study of Unit Root Tests with Panel Data and A New Simple Test, Oxford Bulletin of Economics and Statistics, 61, 631-52.

https://doi.org/10.1111/1468-0084.61.s1.13

Mills, T. C., \& Mills, A. G. (1991). The International Transmission of Bond Market Movements. Bulletin of Economic Research, 43(3), 273-281.

https://doi.org/10.1111/j.1467-8586.1991.tb00496.x

Moghadam, R. (2014). Europe's Road to Integration. Finance \& Development. March 2014, pp. 8-13.

Moon, H. R., \& Perron, B. (2006). Seemingly Unrelated Regressions. The New Palgrave Dictionary of Economics ( $\left.2^{\text {nd }} \mathrm{ed}.\right)$.

Organization for Economic Cooperation and Development (OECD) Data. https://data.oecd.org/

Pagano, M., \& Von Thadden, E. (2004). The European Bond Markets Under EMU. Oxford Review of Economic Policy, 20(4), 531-554. https://doi.org/10.1093/oxrep/grh031

Pedroni, P. (2000). Fully Modified OLS for Heterogeneous Cointegrated Panels. In: Advanced Econometrics, Vol. 15. Nonstationary panels, cointegration in panels and dynamic panels: A survey. Ed. by Baltagi, B.H. and C. Kao.

https://doi.org/10.1016/s0731-9053(00)15004-2

Ramirez, M. (2007). A Panel Unit Root and Panel Cointegration Test of the Complementarity Hypothesis in the Mexican Case, 1960-2001. Atlantic Economic Journal, 35(3), 343-356. https://doi.org/10.1007/s11293-007-9078-6

Schuknecht, L., Moutot, P., Rother, P., \& Stark, J. (2011). The Stability and Growth Pact: Crisis and Reform. European Central Bank Occasional Working Series. No. 129.

Swanson, E. T. (2008). Convergence of Long-Term Bond Yields in the Euro Area. FRBSF Economic Letter. (37).

Taylor, M. P., \& Tonks, I. (1989). The Internationalisation of Stock Markets and the Abolition of U.K. Exchange Control. The Review of Economics and Statistics, 71(2), 332-336. https://doi.org/10.2307/1926980

\section{Appendix A}




\section{Panel Unit Root Tests}

\section{Levin-Lin-Chu Unit Root Test: BAS}

\begin{tabular}{|c|c|c|c|c|}
\hline \multicolumn{4}{|l|}{ Pool unit root test: Summary } & \\
\hline \multicolumn{5}{|c|}{ Series: BAS_AT, BAS_BE, BAS_DE, BAS_EL, BAS_ES, BAS_FI, BAS_FR, } \\
\hline \multicolumn{5}{|c|}{ BAS_IR, BAS_IT, BAS_NL, BAS_PT, BAS_UK } \\
\hline \multicolumn{3}{|l|}{ Sample: 1994M06 2013M12 } & & \\
\hline \multicolumn{5}{|c|}{ Exogenous variables: Individual effects } \\
\hline \multicolumn{4}{|c|}{ Automatic selection of maximum lags } & \\
\hline \multicolumn{5}{|c|}{ Automatic lag length selection based on SIC: 0 to 12} \\
\hline \multicolumn{5}{|c|}{ Newey-West automatic bandwidth selection and Bartlett kernel } \\
\hline & & & Cross- & \\
\hline Method & Statistic & Prob.** & sections & Obs \\
\hline \multicolumn{5}{|c|}{ Null: Unit root (assumes common unit root process) } \\
\hline Levin, Lin \& Chu $\mathrm{t}^{*}$ & -1.96538 & 0.0247 & 12 & 2297 \\
\hline \multicolumn{5}{|c|}{ Null: Unit root (assumes individual unit root process) } \\
\hline Im, Pesaran and Shin W-stat & -6.43414 & 0.0000 & 12 & 2297 \\
\hline ADF - Fisher Chi-square & 118.583 & 0.0000 & 12 & 2297 \\
\hline PP - Fisher Chi-square & 241.740 & 0.0000 & 12 & 2339 \\
\hline
\end{tabular}

\section{Levin-Lin-Chu Unit Root Test: CR}

\begin{tabular}{|c|c|c|c|c|}
\hline \multicolumn{4}{|l|}{ Pool unit root test: Summary } & \\
\hline \multicolumn{5}{|c|}{ Series: CR_AT, CR_BE, CR_DE, CR_EL, CR_ES, CR_FI, CR_FR, CR_IR, } \\
\hline \multicolumn{4}{|c|}{ CR_IT, CR_NL, CR_PT, CR_UK } & \\
\hline \multicolumn{3}{|l|}{ Sample: 1994M06 2013M12 } & & \\
\hline \multicolumn{5}{|c|}{ Exogenous variables: Individual effects } \\
\hline \multicolumn{4}{|c|}{ Automatic selection of maximum lags } & \\
\hline \multicolumn{5}{|c|}{ Automatic lag length selection based on SIC: 0 to 5} \\
\hline \multicolumn{5}{|c|}{ Newey-West automatic bandwidth selection and Bartlett kernel } \\
\hline & & & Cross- & \\
\hline Method & Statistic & Prob.** & sections & Obs \\
\hline \multicolumn{5}{|c|}{ Null: Unit root (assumes common unit root process) } \\
\hline Levin, Lin \& Chu t* & 2.40671 & 0.9920 & 7 & 1571 \\
\hline \multicolumn{5}{|c|}{ Null: Unit root (assumes individual unit root process) } \\
\hline Im, Pesaran and Shin W-stat & 2.89816 & 0.9981 & 7 & 1571 \\
\hline ADF - Fisher Chi-square & 11.3794 & 0.6560 & 7 & 1571 \\
\hline PP - Fisher Chi-square & 13.0354 & 0.5237 & 7 & 1579 \\
\hline
\end{tabular}


Pool unit root test: Summary

Series: INF_AT, INF_BE, INF_DE, INF_EL, INF_ES, INF_FI, INF_FR, INF_IR, INF_IT, INF_NL, INF_PT, INF_UK

Sample: 1994M06 2013M12

Exogenous variables: Individual effects

Automatic selection of maximum lags

Automatic lag length selection based on SIC: 0 to 12

Newey-West automatic bandwidth selection and Bartlett kernel

\begin{tabular}{|l|c|c|c|c|}
\hline & & & Cross- & \\
\hline Method & Statistic & Prob.** & sections & Obs \\
\hline Null: Unit root (assumes common unit root process) \\
\hline Levin, Lin \& Chu t* & 0.64575 & 0.7408 & 12 & 2739 \\
\hline Null: Unit root (assumes individual unit root process) \\
\hline Im, Pesaran and Shin W-stat & -5.50803 & 0.0000 & 12 & 2739 \\
\hline ADF - Fisher Chi-square & 77.4758 & 0.0000 & 12 & 2739 \\
\hline PP - Fisher Chi-square & 72.2242 & 0.0000 & 12 & 2808 \\
\hline ** Probabilities for Fisher tests are computed using an asymptotic Chi \\
\hline
\end{tabular}

\section{Appendix B}

\section{Fully Modified Ordinary Least Squares (FMOLS)}

\begin{tabular}{|c|c|c|c|c|}
\hline \multicolumn{3}{|c|}{ Dependent Variable: $\mathrm{Y}$} & & \\
\hline \multicolumn{5}{|c|}{ Method: Panel Fully Modified Least Squares (FMOLS) } \\
\hline \multicolumn{4}{|c|}{ Sample (adjusted): 1995M02 2013M12 } & \\
\hline \multicolumn{3}{|c|}{ Periods included: 227} & & \\
\hline \multicolumn{3}{|c|}{ Cross-sections included: 4} & & \\
\hline \multicolumn{4}{|c|}{ Total panel (unbalanced) observations: 861} & \\
\hline \multicolumn{4}{|c|}{ Panel method: Pooled estimation } & \\
\hline \multicolumn{4}{|c|}{ Cointegrating equation deterministics: $\mathrm{C}$} & \\
\hline \multicolumn{5}{|c|}{ Long-run covariance estimates (Bartlett kernel, Newey-West fixed } \\
\hline \multicolumn{3}{|l|}{ bandwidth) } & & \\
\hline Variable & Coefficient & Std. Error & t-Statistic & Prob. \\
\hline BAS & 3.043580 & 0.539519 & 5.641286 & 0.0000 \\
\hline $\mathrm{CR}$ & -0.169482 & 0.022442 & -7.551883 & 0.0000 \\
\hline INF & 0.158655 & 0.154932 & 1.024032 & 0.3061 \\
\hline D2 & 3.530533 & 2.816536 & 1.253502 & 0.2104 \\
\hline D3 & 2.172101 & 2.438871 & 0.890618 & 0.3734 \\
\hline D4 & 2.624794 & 2.447062 & 1.072631 & 0.2837 \\
\hline R-squared & 0.703533 & \multicolumn{2}{|c|}{ Mean dependent var } & 5.129947 \\
\hline Adjusted R-squared & 0.697555 & \multicolumn{2}{|c|}{ S.D. dependent var } & 3.027651 \\
\hline S.E. of regression & 1.665057 & \multicolumn{2}{|c|}{ Sum squared resid } & 2337.146 \\
\hline Long-run variance & 23.18293 & & & \\
\hline
\end{tabular}

\section{Copyright Disclaimer}

Copyright for this article is retained by the author(s), with first publication rights granted to the journal.

This is an open-access article distributed under the terms and conditions of the Creative Commons Attribution license (http://creativecommons.org/licenses/by/3.0/). 